\section{Vuk Radmilovic*}

\section{"Treaty Federalism: Reconceptualizing Aboriginal-State Relations in Canada"}

*In December 2003, Vuk Radmilovic completed a Bachelor of Arts degree in Political Science at Simon Fraser University.

\section{Introduction}

It is inconceivable, I think, that in a given society, one section of the society have a treaty with the other section of society. We must all be equal under the laws and we must not sign treaties amongst ourselves. ${ }^{1}$ Pierre Elliot Trudeau - 1969

[T] he terms of the Canadian federation are found not only in formal constitutional documents governing relations between the federal and provincial governments but also in treaties and other instruments establishing the basic links between Aboriginal peoples and the Crown. ${ }^{2}$

Royal Commission on Aboriginal Peoples - 1996

For over three decades now, a period during which Aboriginal peoples in Canada have more vigorously pursued the recognition of their political and social status than during previous centuries, the Canadian polity has been faced with considerable challenges in attempting to accommodate the political aspirations of the Aboriginal peoples. A wide variety of proposals for a renewed relationship between Aboriginal and non-Aboriginal Canadians have been put forward, most of which typically revolve around the concept of Aboriginal self-government. Indeed, it seems that the debate over the legitimacy of Aboriginal self-government aspirations is over and that questions of implementation have taken the centre stage. ${ }^{3}$ One of the proposals for a renewed relationship that has generated an ample amount of discussion from both the legal and political academic communities is the concept of treaty federalism. At the most general level, treaty federalism calls for a reconceptualization of the relationship

\footnotetext{
${ }^{1}$ As quoted in, Russel Lawrence Barsh and James Youngblood Henderson,

"Aboriginal Rights, Treaty Rights, and Human Rights: Indian Tribes and

"Constitutional Renewal"," Journal of Canadian Studies 17: 2 (Summer, 1982): 69-70.

${ }^{2}$ Royal Commission on Aboriginal Peoples, Report (Ottawa: Supply and Services Canada, 1996), II, p. 194.

${ }^{3}$ Jodi Cockerill and Roger Gibbins, "Reluctant Citizens? First Nations in the Canadian Federal State," in First Nations in Canada: Perspectives on Opportunity, Empowerment, and Self-Determination, ed. J.R. Ponting (Toronto: McGraw-Hill Ryerson, 1997), p. 384.
}

between Aboriginal peoples and the Canadian state that would affirm Aboriginal peoples' long standing claims to sovereignty and the right to self-determination. While the idea of treaty federalism has been positively received by various Aboriginal communities and various Aboriginal and non-Aboriginal scholars, it has also provoked some very unfavorable assessments usually with respect to its theoretical foundations and general workability. This paper will examine the concept of treaty federalism with respect to Canadian Aboriginal-state relations. The central thesis of the paper is that the idea of treaty federalism has a potential to significantly improve Aboriginal-state relations in Canada. Indeed, treaty federalism can set the stage for a true reconciliation between Aboriginal and non-Aboriginal Canadians based on such notions as equality and consent. This reconciliation would follow a long tradition of federal treaty relationships between Aboriginal peoples and the Canadian state. This is not to suggest, however, that the implementation of the treaty federalism paradigm will not impose considerable practical and theoretical challenges to Aboriginal-state relations in Canada. In fact, the recognition of political aspirations of Canadian Aboriginal peoples on the basis of treaty federalism is possible only through a sustained effort on the part of both Aboriginal peoples and the Canadian state.

This paper will proceed with a brief overview of a general theory of federalism - whose main purpose is to provide a conceptual framework for examining treaty federalism in the Canadian context - after which an examination of Canadian discourses of treaty federalism will follow. From this backdrop, the paper will present an analysis of treaty federalism in Canada which will outline the case for treaty federalism and also address main points of criticism leveled against the treaty federalism paradigm in Canada.

\section{Federalism}

As forms of institutional organization, federalism in general and federal political systems (federations) in particular, have been widely used throughout the world as a basis for accommodating interests and concerns of distinct groups within a political system. ${ }^{4}$ Organizing political systems along federal lines has been particularly attractive for multiethnic states because of several basic features that characterize a federation. At the most basic level, federal systems are characterized by the existence of "more than one level of government over the same geographical

\footnotetext{
${ }^{4}$ For a distinction between federalism and federal political systems (federations) see Ronald L. Watts, Comparing Federal Systems (Montreal \& Kingston: McGill-Queen's University Press, 1999), p. 6-7. Watts furthermore notes that "there are at present twenty-three countries encompassing over 40 percent of the world's population that exhibit the fundamental characteristics of a federation." Watts, xi.
} 
territory." A more fundamental point, however, is that relations between levels of government in a federation are inevitably characterized by a balance between "political integration and political freedom [through] combining shared-rule on some matters with self-rule on others within a system founded on democratic consent" (emphasis in the original). ${ }^{6}$ This balance between integration and freedom among different levels of government - i.e. the federal government and the governments of the constituent units is made possible by the fact that in federal systems sovereignty is not in the absolute possession of any one level of government. On the contrary, each level of government is sovereign within the domains of particular, constitutionally outlined, jurisdictions. For that reason, the most important aspect of federations is that they "involve co-ordinacy (i.e. non-subordination in the exercise of authority) ... [in a sense that] [e]ach order of government has its own constitutionally specified authority and none can dictate to the others." 7

Another aspect of federations that needs to be emphasized is that apart from outlining jurisdictions of shared-rule and self-rule between different levels of government, successful federal systems also involve a degree of national unity that transcends sub-state arrangements. The idea of national unity is usually expressed through such notions as common citizenship and 'common fellow-feeling' that individual citizens of federations share. Beside creating connections between individual citizens and sub-federal governments, federations also involve direct links between the federal/national government and individual citizens. This multiplicity of citizen-government connections is an essential characteristic of federal systems because division of jurisdictional sovereignty between different levels of government implies that individual citizens will depend upon different levels of government for different services. It seems that individual members of federal states are, therefore, required to balance multiple loyalties - subfederal and national. The existence of national loyalties ensures that federal states remain something more than a mere "container" of sub-federal loyalties. ${ }^{8}$ It is in this regard that federal arrangements are often praised for their ability to "secure, within deeply-divided societies, social

\footnotetext{
${ }^{5}$ Robert J. Jackson and Doreen Jackson, An Introduction to Political Science: Comparative and World Politics (Toronto: Prentice Hall, 2003), p. 211.

${ }^{6}$ Ronald L. Watts, Federal Systems and Accommodation of Distinct Groups: A Comparative Study of Institutional Arrangements for Aboriginal Peoples (Kingston: Queen's University, Working Paper 1998(3)), p. 4. Paraphrasing Proudhon, Graham Smith refers to the balance between political integration and political freedom as "the reconciliation of authority and liberty." See, Graham Smith, ed., The Multiethnic Challenge (London and New York: Longman, 1995), p. 6.

${ }^{7}$ Watts, Federal Systems and Accommodation of Distinct Groups: A Comparative Study of Institutional Arrangements for Aboriginal Peoples, p. 5 .

${ }^{8}$ Importantly, it may also ensure sharing and transfer of resources among and within different levels of government.
}

unity and political stability ... [or to bring about] the celebration of diversity through unity" (emphasis added). ${ }^{9}$

The final characteristic of federal political systems that will be considered here is the notion of consent. As it has been suggested above, political arrangements within federal systems are founded upon the consent of all levels of government. The notion of consent is usually illustrated by the fact that a written constitution - which distributes "legislative and executive authority and [allocates] revenue resources between ... orders of government, including some areas of autonomy for each" - is "not unilaterally amendable by either order of government, and amendments requir[e] the consent of at least a majority of the constituent units." $"$ Sub-federal constituent units are, therefore, ensured that constitutional provisions outlining federal arrangements will not be abrogated without at least a substantial degree of consent on their part. Moreover, and as it is relevant to the discussion of treaty federalism that follows, the constitutional amendment process ensures subfederal constituent units' participation in discussions that may lead to formal changes to the constitutional arrangements.

\section{Understanding Treaty Federalism}

One of the most important ideas around which the theory of treaty federalism in Canada has been constructed is that the treaties that were (and continue to be) signed between Canadian Aboriginal peoples and the Canadian state amount to federal relationships (even though they may not be recognized as such by dominant contemporary Canadian federal thought). Treaty federalism, therefore, is ultimately a call for federal recognition of the treaty relationships between Aboriginal peoples and the Canadian state. In the words of James Youngblood Henderson, the idea of treaty federalism calls for an "expansion of contemporary thought about federalism" in Canada and for the creation of an additional federal order within the Canadian state. ${ }^{11}$ The new order, which would be added to the existing provincialfederal order, is to be based on treaty relationships between Aboriginal peoples and the Canadian state. Importantly, the idea of treaty federalism assumes that treaties in general, and the early treaties that were concluded between Aboriginal peoples and European settlers in particular, are "international in nature" in the sense that they represent contracts between independent self-governing entities. Such nation-to-nation contracts were not intended to create a single sovereign power; rather, they were "agreements between independent powers that recognized the autonomy of each nation [that is, various Aboriginal nations, and nations descending from European settlers] and the ability of each to determine their political status vis-à-vis the

\footnotetext{
${ }^{9}$ Smith, 4-5.

${ }^{10}$ Watts, Federal Systems and Accommodation of Distinct Groups, p. 6.

${ }^{11}$ James [sakey] Youngblood Henderson, "Empowering Treaty

Federalism," Saskatchewan Law Review 58: 94 (1994): 242.
} 
other."12 Accordingly, the existing treaties amount to federal arrangements because of the fact that they entail issues of divided sovereignty and shared responsibilities, and because they "imply a balance between autonomy and mutual obligation among the participants" (emphasis in the original). ${ }^{13}$ In the minds of treaty signatories, treaties amounted to the creation of "permanent political relationship[s]," that were based on the consent of the peoples whom signatories represented. ${ }^{14}$ As such, treaty relationships between Aboriginal peoples and the Canadian state amount to federal arrangements.

Treaty federalism furthermore proposes that any legislative power of the federal or provincial governments over Aboriginal peoples that is not based on existing treaties is illegitimate because Aboriginal peoples, as autonomous and self-determining entities, have retained all powers "that they did not expressly give up" through treaties. ${ }^{15}$ This assertion is further supported by the writings of Will Kymlicka who notes that treaties do not imply the "renunciation of [the] original right of self government" by Aboriginal communities. "Rather," Kymlicka notes, "it is a matter of transferring some aspect of their powers of selfgovernment to the larger polity, on the condition that other powers remain in their own hands" (emphasis in the original). ${ }^{16}$ In sum, therefore, treaty federalism calls for a modern reestablishment of the early treaty-based relationships that existed between European settlers and Aboriginal peoples and that were characterized by shared responsibilities in the face of mutual autonomy.

The notion of treaty federalism, as briefly outlined above, inevitably questions the basic principles of the Canadian Constitution. In particular, it argues that early and more recent treaty relationships between Aboriginal peoples and the Canadian state are an inherent part of the Canadian constitution. For this reason, the Canadian Constitution is still considered to be "colonial" (and not "modern") to the extent that it fails to embody the tradition of treaty relationships between Aboriginal peoples and nonAboriginal Canadians. As well as calling for an expansion of Canadian federalist thought, treaty federalism, therefore, also calls for an expansion of Canadian constitutional thought. In this context, Brian Slattery has differentiated between the imperial and the organic Canadian

\footnotetext{
${ }^{12}$ Kiera L. Ladner, "Negotiated Inferiority: The Royal Commission on Aboriginal People's Vision of a Renewed Relationship," American Review of Canadian Studies 31:1/2 (Spring/Summer 2001): 250.

${ }^{13}$ Thomas O. Hueglin, Exploring Concepts of Treaty Federalism: A Comparative Perspective (Paper Prepared for the Institute of Intergovernmental Relations Queen's University on Behalf of the Royal Commission on Aboriginal Peoples. Waterloo, Ontario, December 1993). $<<$ http://www.wlu.ca/ wwwpolsc/facpages/hueglin/treaty.htm $>>$

${ }^{14}$ Russel Lawrence Barsh and James Youngblood Henderson, The Road: Indian Tribes and Political Liberty (Los Angeles: University of California Press, 1980), p. 276.

${ }^{15}$ Barsh and Henderson, “Aboriginal Rights, Treaty Rights, and Human Rights," p. 66.

${ }^{16}$ Will Kymlicka, Multicultural Citizenship: A Liberal Theory of Minority Rights (Oxford: Clarendon Press, 1995), p. 181.
}

Constitution. According to Slattery, the organic Constitution of Canada is open to "a variety of perspectives that have long been excluded or assigned to the periphery of [Canadian] collective life," and it includes the recognition of the "diverse roles that Indian, Inuit, and Metis peoples have played in the formation of this country and its Constitution." ${ }^{17}$ It is important to note that the Canadian Constitution has already recognized some aspects of treaty federalism through section 35 of the Constitution Act, 1982. While the Canadian Constitution is in this sense composed of both "colonial and modern" aspects, treaty federalism calls for a further consolidation of post-colonial (i.e. modern) constitutional thinking that would lead towards greater incorporation of the treaty-based arrangements between Aboriginal peoples and the Canadian state in the Canadian political process. ${ }^{18}$

There is a long and elaborate tradition of treatyrelationships between Aboriginal peoples and the Canadian state. In fact, even prior to the arrival of European settlers on the North American continent, Aboriginal peoples were engaged in the creation of federal-like treaty relationships in order to arrange their own political relationships. As Tully notes, treaty relationships that Aboriginal peoples established among themselves prior to European arrival were expressions of "multinational federalism by means of treaty-making." ${ }^{\prime 19}$ Once European settlers arrived, Aboriginal peoples occupying what are now Canadian lands simply continued their long-established practice of pursuing treaty relationships with other nations and started 'treating' their relations with European settlers. The treaties between Aboriginal peoples and the emerging Canadian state were generally based on the so-called two-row wampum nationto-nation model which emphasized such values as consent, continuity, "equality, respect, dignity and a sharing of the river we travel on. ${ }^{20}$ The two-row wampum - "One River, Two Vessels" - model generally symbolizes a peaceful relationship between Aboriginal nations and nations descending from European settlers according to which "the First Nations and Europeans would travel in parallel paths down the symbolic river in their own vessels." ${ }^{21}$ Over the

\footnotetext{
${ }^{17}$ Brian Slattery, "The Organic Constitution: Aboriginal Peoples and the Evolution of Canada" Osgoode Hall Law Journal 34:1 (Spring, 1995): 111. See also, James Tully, Strange Multiplicity: Constitutionalism in an age of diversity (Cambridge: Cambridge University Press, 1995); Brian Slattery, "The Hidden Constitution: Aboriginal Rights in Canada," in The Quest for Justice: Aboriginal Peoples and Aboriginal Rights, ed., Menno Boldt and J. Anthony Long (Toronto: University of Toronto Press, 1985. ${ }^{18}$ Henderson, 242. The terminology of modern/post-colonial and colonial is taken from Henderson, Empowering Treaty Federalism.

${ }^{19}$ James Tully, "Multirow Federalism and the Charter," in Protecting Rights and Freedoms: Essays on the Charter's Place in Canada's Political, Legal, and Intellectual Life, ed, Philip Bryden, Steven Davis, and John Russel (Toronto: University of Toronto Press, 1994), p. 188. For a comparison between Aboriginal and Euro-Canadian visions of federalism see Hueglin,

$<<$ http://www.wlu.ca/ wwwpolsc/facpages/hueglin/treaty.htm>>

${ }^{20}$ Ovide Mercedi and Mary Ellen Turpel, In The Rapids: Navigating the

Future of First Nations (Toronto: Viking, 1993), 35.

${ }^{21}$ Ibid., 35.
} 
centuries, the treaty-making process based on the two-row wampum model resulted in an elaborate web of treaty relations encompassing more than 500 treaties between Aboriginal peoples and the Canadian state. ${ }^{22}$

Nevertheless, at some unspecified historical moment after the Royal Proclamation of 1763 - which arguably, and according to U.S. Chief Justice John Marshal, recognized Aboriginal sovereignty and legally legitimated nation-tonation relationships ${ }^{23}$ - the nation-to-nation character of relationships between Aboriginal peoples and the Canadian state changed. The approach of the Canadian state towards Aboriginal peoples increasingly became characterized by notions of dependency and 'wardship'. The best illustration of this shift in understanding on the part of the Canadian governments with respect to the Aboriginal-state relations is Indian Act of 1876. The Act, notorious for the fact that it provided the Canadian state with powers to regulate all aspects of Aboriginal peoples' lives, was (and still is) in clear conflict with the nation-to-nation understanding of treaty relationships. As Barsh and Henderson note, the Indian Act invested the Canadian state with "all powers ever delegated by any tribe, to be exercised uniformly over all tribes" (emphasis in the original). ${ }^{24}$ A likewise understanding of Aboriginal-state relations by successive Canadian governments persisted well into the twentieth century having its final epitome in the so-called White Paper of $1969 .^{25}$

Since 1969, Aboriginal peoples have come a long way in having their political aspirations recognized in Canada. In this respect, section 35(1) of the Constitution Act, 1982 has a particularly important symbolic significance because, as Slattery notes, the Canadian constitution "now clearly acknowledges the historical role of native peoples in the making of Canada," 26 and it also recognizes the existence of Aboriginal treaty rights.

\section{Assessing Treaty Federalism in Canada}

As it was suggested above, the early treaties that were concluded between Aboriginal peoples and the Canadian state are federal in nature because they involve several fundamental characteristics of federalism. Above all, these treaties amount to federal relationships because of the fact that they entail issues of divided sovereignty, and because they are based on the notion of consent. Within the

\footnotetext{
${ }^{22}$ Tully, "Multirow Federalism and the Charter," p. 188. In this context, Tully notes that " $[\mathrm{t}]$ wo-row and multirow wampum belts are the traditional lingua franca of federal politics in Canada." $\mathrm{p}, 189$.

${ }^{23}$ Ibid., 191. In this context, the words of Chief Justice John Marshal are very telling: "The words 'treaty' and 'nations' are words of our own language, selected in our diplomatic and legislative proceedings by ourselves, having each a definite and well understood meaning. We have applied them to Indians, as we have applied them to the other nations of the earth. They are applied to all in the same sense." Quoted in Tully, Strange Multiplicity, p. 120.

${ }^{24}$ Barsh and Henderson, 64.

${ }^{25}$ In the context of which Trudeau's words from the outset of this paper were voiced.

${ }^{26}$ Slattery, “The Hidden Constitution," p. 137.
}

Canadian state, therefore, there are two parallel federal orders - the provincial-federal order established by the British North America Act of 1867 and the treaty-order governing the relationships between Aboriginal peoples and the Canadian state which was partially recognized via section 35(1) of the Constitution Act, 1982. According to Ronald Watts, "[an] important task [that remains] ... is to synchronize these two kinds of federal relationships into a practical harmony." ${ }^{27}$ Indeed, as the following discussion will illustrate there are some compelling reasons to do just that.

Probably the most important reason for fully embracing treaty-federalism in Canada is to correct the historical injustices that were committed against Canadian Aboriginal peoples. As it was noted above, the early treaties that were conducted between Aboriginal peoples and the Canadian state were, at least in the minds of Aboriginal peoples, expected to create enduring political relationships. The clear abrogation of these treaties by successive Canadian authorities - as exemplified by the Indian Act of 1876 - led to the loss of Aboriginal peoples' rights to self-government and self-determination even in those areas where they retained their sovereignty through treaties. It is probably not an understatement to say that this had tremendous detrimental consequences on Canadian Aboriginal communities.

Another reason for the espousal of the treaty federalism model in Canada that is closely related to the above discussion of correcting historical injustices is the fact that treaty relations between Aboriginal peoples and the Canadian state are a major component of the Canadian political history. As Kymlicka notes, treaty agreements outlining Aboriginal-state relations played a vital role in the creation and expansion of Canada. ${ }^{28}$ This argument, therefore, calls for a further reconciliation of the two federal orders in Canada on the basis of recognizing contributions that Aboriginal peoples - and Aboriginal-state relations had on the development of the Canadian state and the Canadian political system.

In spite of these reasons that suggest that treaty federalism ought to be fully embraced by the Canadian political community, the notion of treaty federalism has generated a considerable amount of negative assessments stemming mostly from the academic community of Canadian political scientists. The following paragraphs will proceed with the discussion of treaty federalism by addressing two such criticisms.

The first criticism is based on the idea that treaty federalism is ill suited for Canada because it generally undermines, or fails to embody, a sense of "common fellow-feeling" between Aboriginal peoples and nonAboriginal Canadians that is essential in any federal

\footnotetext{
${ }^{27}$ Watts, Federal Systems and Accommodation of Distinct Groups, 9.

${ }^{28}$ Kymlicka, 119.
} 
arrangement. ${ }^{29}$ In this respect, LaSelva, for example, notes that "a compact theory [of treaty federalism] captures only one side of federalism," while ignoring the other side that includes such notions as "common citizenship, common allegiances, and a common frame of government. ${ }^{" 30}$ Cairns goes a step further and suggests that "in much of this literature [including the legal academic writings on treaty federalism as espoused by Henderson] there is a deep, if implicit strain of separatism." ${ }^{31}$ These analyses are usually accompanied by an argument that treaty federalism ignores significant interdependencies that exist between Aboriginal and non-Aboriginal peoples in Canada, and that it meaningfully focuses only on those Aboriginal groups that have a land base ignoring the large segments of the Aboriginal populations that live in urban areas.

With respect to the Cairns' argument that Canadian writings on treaty federalism espouse an "implicit strain of separatism" it is important to point out that the vast majority of Aboriginal peoples in Canada are not seeking independence from the Canadian state as their ultimate goal. In fact, as Barsh and Henderson note:

$$
\text { ...treaty federalism ... is a procedure for the }
$$

creative establishment of governments in circumstances where conventional statehood would be economically, socially or politically inappropriate, but where both sovereignties recognize the expediency of permanent union (emphasis added). ${ }^{32}$

It may be true, on the other hand, that Aboriginal peoples in today's Canada often present arguments for the recognition of their rights in what may appear as uncompromising terms. This, however, could be explained by the fact that it is only natural for Canadian Aboriginal peoples, who continue to struggle to rid themselves of the colonial yoke, to overwhelmingly focus their political action on emphasizing their differences from the majority society while undermining similarities in order to have their grievances recognized and addressed. This may account for the "implicit strain of separatism" that runs through much of the legal literature on treaty federalism. As Cairns' himself has aptly argued in a different context, "[t]hat imperialism was a comprehensive way of life generates an equally comprehensive counterattack., 33

Cairns and LaSelva are correct in pointing out that a sense of "common fellow-feeling" among different groups composing a federation is essential in any federal arrangements. As it was argued above, a degree of national unity that transcends sub-federal arrangements is necessary

\footnotetext{
${ }^{29}$ See, for example, Samuel V. LaSelva, Moral Foundations of Canadian Federalism: Paradoxes, Achievements and Tragedies of Nationhood (Montreal: McGill-Queen's University Press, 1996), p. 137-155. See also, Alan C. Cairns, Citizens Plus: Aboriginal Peoples and the Canadian State (Vancouver: UBC Press, 2000), p.179-213.

${ }^{30}$ LaSelva, 151.

${ }^{31}$ Cairns, 184.

${ }_{32}^{32}$ Barsh and Henderson, The Road, p. 275.

${ }^{33}$ Cairns, 44.
}

in order to keep the federal state together and united in its diversity. However, the argument that treaty federalism captures only that side of federalism which promotes autonomy for the constituent units while ignoring such notions as "common citizenship, common allegiances, and a common frame of government" is questionable. The problem with this line of reasoning is that it ignores the above noted fact that Canadian authorities breached obligations that they themselves had committed to by entering into treaty relationships with Canadian Aboriginal peoples. The emergence of strong feelings of "common allegiances, and a common frame of government" in relations between Aboriginal peoples and the Canadian state is possible only after 'the other side of federalism' has been established - i.e. the entrenchment of treaty relationships between Aboriginal peoples and the Canadian state based on consent and notions of shared responsibilities in the face of mutual autonomy. As Kymlicka notes precisely in this regard, "[r]espect for treaty agreements is important ... not only to respect the self-determination of the minority, but also to ensure that citizens have trust in the actions of government." 34 Only after the recognition of treaty relations in their full institutional consequence by the Canadian state could significant interdependencies that already exist between Aboriginal and non-Aboriginal peoples serve as a basis for the emergence of a true sense of national unity - an end result that would benefit both Aboriginal peoples and the Canadian state.

The second criticism of treaty federalism is based on the argument that constitutional arrangements that support the notion of treaty federalism are simply unworkable because they would put unbearable strain on the existing institutions of Canadian federalism. This argument is clearly expressed in the writings of Cockerill and Gibbins. They note that "[s]imply put, some six hundred selfgoverning First Nations, or even $10 \%$ of that number, could not be worked into the full array of existing intergovernmental structures." ${ }^{35}$ Accordingly, it would simply be unfeasible for different Aboriginal peoples to have their own particular treaty relations with the Canadian state.

This argument exposes a larger obstacle for the recognition of treaty federalism in Canada; namely, as Hueglin points out, that:

[t]o most political scientists as well as practitioners, federalism today has come to mean not much more than 'intergovernmental relations', a mechanism of organizing the political process under a given constitutional order, or of changing that order according to necessities of political expediency and conflict regulation, but it rarely means a quest for principles and visions of a good life that still would have to be found - or rediscovered. ${ }^{36}$

\footnotetext{
${ }^{34}$ Kymlicka, 119.

${ }^{35}$ Cockerill and Gibbins, 385.

${ }^{36}$ Hueglin,

$<<$ http://www.wlu.ca/ wwwpolsc/facpages/hueglin/treaty.htm $>>$
} 
Similarly, but in a different context, Kymlicka notes that critics of policies that accord 'special status' to particular groups within a federation are often "prisoners of their own a priori definitions of federalism or a priori assumptions about the possible basis of unity." ${ }^{37}$ This points to the degree to which Canadian contemporary federalist thought needs to 'flex its muscles' in order to accommodate treaty federalism.

Even though the challenge is great, several points that can ease the process of reconciliation of treaty federalism with the Canadian provincial-federal order need to be pointed out. First, varying degrees of Aboriginal peoples' self-governing capacity and interdependence with the larger Canadian community mean that not all treaty relationships will be the same. In other words, not all Aboriginal peoples will seek the establishment of full-fledged "intergovernmental relations" with the Canadian state. Second, various Aboriginal peoples may come together and organize their own relations in such a way that would ease the mechanics of the future relations with the Canadian state. Such actions may be attractive for Aboriginal peoples because they may enable those Aboriginal communities with weak self-governing capacity to arrange their relations with the Canadian state under favourable terms. Finally, it seems unfair to suggest that the goal of Aboriginal recognition within the Canadian state is to be jeopardized by the mere complexity of future relations. In light of the "historic wrongs" committed against Aboriginal peoples by the Canadian state which were briefly discussed above, Canada has a moral duty to go out of its way to accommodate Aboriginal peoples. Furthermore, taking into account positive developments that have occurred in Aboriginal-state relations since the collapse of the 1969 White Paper - including the inclusion of the section 35(1) in the Constitution Act, 1982, and the continuation of the treaty process through 'modern treaties' - it seems inevitable that treaty federalism will serve as a basis for Canadian Aboriginal-state relation in the mid to long-term future.

\section{Conclusion}

This paper has argued that contrary to the above discussed critics of treaty federalism, the idea of treaty federalism can indeed serve as a basis for the reconceptualization of the relationship between Aboriginal peoples and the Canadian state that would ultimately serve the interests of both Aboriginal peoples and non-Aboriginal Canadians. On the one hand, treaty federalism could affirm Aboriginal peoples' long standing claims to sovereignty and the right of self-determination. On the other hand, treaty federalism could establish the necessary conditions for the development of a stronger sense of social and political unity

\footnotetext{
${ }^{37}$ Will Kymlicka, "Individual and Community Rights," in Group Rights (Toronto: University of Toronto Press, 1994), 27.
}

between Aboriginal peoples and the Canadian state. The common denominator for both of these goals is the reestablishment of federal-like treaty relationships regulating Aboriginal-state relations that are characterized by shared responsibilities in the face of mutual autonomy and consent. The greatest obstacle to this development is presented in the form of structural difficulties pertaining to the reconciliation of the treaty federalism paradigm with the Canadian provincial-federal order. Then again, the great strides that have been made in the re-conceptualization of the relationship between Aboriginal peoples and the Canadian state since the early 1970 s seem to suggest that the progress towards treaty federalism is on the horizon. On balance, what makes the entrenchment of treaty federalism in the Canadian federal order seem almost inevitable is the nexus of legal, moral, and political arguments that push in that direction. $\mathrm{O}$

\section{Bibliography:}

Barsh, Russel Lawrence and James Youngblood Henderson. "Aboriginal Rights, Treaty Rights, and Human Rights: Indian Tribes and "Constitutional Renewal"," Journal of Canadian Studies 17:2 (Summer, 1982); pp. 55-81.

Barsh, Russel Lawrence and James Youngblood Henderson. The Road: Indian Tribes and Political Liberty. Los Angeles: University of California Press, 1980.

Cairns, Alan C. Citizens Plus: Aboriginal Peoples and the Canadian State. Vancouver: UBC Press, 2000.

Cockerill, Jodi and Roger Gibbins. "Reluctant Citizens? First Nations in the Canadian Federal State," In First Nations in Canada: Perspectives on Opportunity, Empowerment, and SelfDetermination. ed. by J. Rick Ponting. Toronto: McGraw-Hill Ryerson Limited, 1997, pp. 383-403

Henderson, James [sakey] Youngblood. "Empowering Treaty Federalism," Saskatchewan Law Review, 58 (1994): pp. 241-329.

Henderson, James [sakey] Youngblood. "Implementing The Treaty Order," In Continuing Poundmaker and Riel's Quest. ed. Richard Gosse et al. Saskatoon: Purich Publishing, 1994, pp. 5262.

Hueglin, Thomas O. Exploring concepts of Treaty Federalism. Paper Prepared for the Institute of Intergovernmental Relations Queen's University on Behalf of the Royal Commission on Aboriginal Peoples. Waterloo, Ontario, December 1993. $<<$ http://www.wlu.ca/ wwwpolsc/facpages/hueglin/treaty.htm $>>$

Jackson, Robert J. and Doreen Jackson. An Introduction to Political Science: Comparative and World Politics. (Toronto: Prentice Hall, 2003).

Royal Commission on Aboriginal Peoples, Report (Ottawa: Supply and Services Canada, 1996), II. 
Kymlicka, Will. Multicultural Citizenship: A Liberal Theory of Minority Rights. Oxford: Clarendon Press, 1995.

Kymlicka, Will. "Individual and Community Rights." In Group Rights. ed. Judith Baker. Toronto: University of Toronto Press, 1994, pp. 17-33.

Ladner, Kiera. "Negotiated Inferiority: The Royal Commission on Aboriginal Peoples' Vision of a Renewed Relationship," American Review of Canadian Studies 31 (Spring/Summer 2001): pp. 241-264.

LaSelva, Samuel V. Moral Foundations of Canadian Federalism: Paradoxes, Achievements, and Tragedies of Nationhood. Montreal: McGill University Press, 1996.

Mercedi, Ovide, and Mary Ellen Turpel,. In the Rapids: Navigating the Future of First Nations. Toronto: Viking, 1993.

Smith, Graham. ed., The Multiethnic Challenge (London and New York: Longman, 1995).

Slattery, B. "The Hidden Constitution of Canada: Aboriginal Rights in Canada," In The Quest for Justice. ed. Menno Boldt and
J. Anthony Long. Toronto: University of Toronto Press, 1985, pp. 114-138.

Slattery, B. "The Organic Constitution: Aboriginal Peoples and the Evolution of Canada," Osgoode Hall Law Journal. 34 (1995): pp. 101-112.

Tully, James. "Multirow Federalism and the Charter." In Protecting Rights and Freedoms. ed. Philip Bryden et al. Toronto: University of Toronto Press, 1994, pp. 178-204.

Tully, James. Strange Multiplicity: Constitutionalism in an Age of Diversity. Cambridge University Press, 1995.

Watts, Ronald L. Federal Systems and Accommodation of Distinct Groups: A Comparative Study of Institutional Arrangements for Aboriginal Peoples. Institute of Intergovernmental Relations. Working Paper 1998(3).

Watts, Ronald L. Comparing Federal Systems. (Montreal \& Kingston, 1999).

White, Graham. "Treaty Federalism in Northern Canada: Aboriginal-Government Land Claims Boards," Publius: The Journal of Federalism 32:3 (Summer 2002): pp. 89-114. 